\title{
INTERAÇÃO ENTRE ORTODONTIA E DENTÍSTICA EM UM CASO CLINICO DE DISCREPÂNCIA DE BOLTON
}

Adriana Lemos Mori UBALDINI, Renata Corrêa PASCOTTO

Finalização estética pós-tratamento ortodôntico: Muitas alternativas têm sido propostas para a finalização de tratamentos ortodônticos na presença de diastemas múltiplos remanescentes em função da discrepância dentária de Bolton. Os autores apresentam um caso clínico de abordagem multidisciplinar, onde após a terapia ortodôntica realizou-se um guia de silicone a partir do enceramento diagnóstico do modelo de gesso, que serviu como referência na orientação dos incrementos de resina composta realizada pela técnica direta. Pretende-se, com este trabalho, ressaltar a importância da contribuição da dentística restauradora na finalização e acabamento de casos ortodônticos. O uso da resina composta na técnica direta mostrou ser uma alternativa conservadora, previsível e totalmente reversível, uma vez que nenhum tipo de preparo cavitário ou desgaste de estrutura dental sadia foi realizado uma vez que os dentes estavam bem posicionados.

Palavras- chave: Diastema, Resina Composta, Odontologia. 